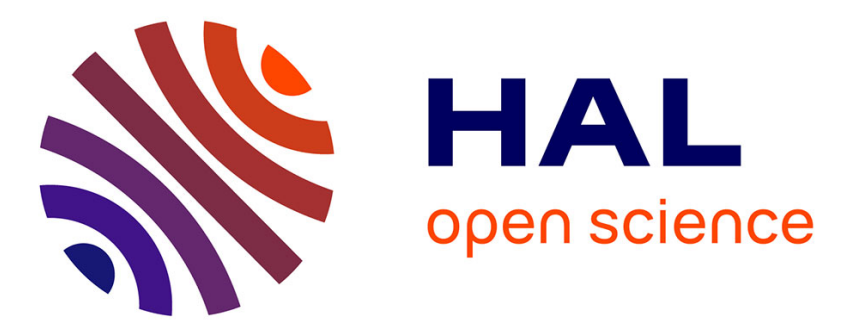

\title{
Drivers of growth: the case of French academic spin-off
}

Véronique Bessière, Marie Gomez Breysse, Karim Messeghem, Andry

Ramaroson, Sylvie Sammut

\section{To cite this version:}

Véronique Bessière, Marie Gomez Breysse, Karim Messeghem, Andry Ramaroson, Sylvie Sammut. Drivers of growth: the case of French academic spin-off. International Journal of Entrepreneurship and Innovation Management, 2017, The growth of academic spin-offs, 21 (4/5), pp.318-342. 10.1504/IJEIM.2017.085684 . hal-01995316

\section{HAL Id: hal-01995316 https://hal.science/hal-01995316}

Submitted on 26 Jan 2019

HAL is a multi-disciplinary open access archive for the deposit and dissemination of scientific research documents, whether they are published or not. The documents may come from teaching and research institutions in France or abroad, or from public or private research centers.
L'archive ouverte pluridisciplinaire HAL, est destinée au dépôt et à la diffusion de documents scientifiques de niveau recherche, publiés ou non, émanant des établissements d'enseignement et de recherche français ou étrangers, des laboratoires publics ou privés. 


\section{International Journal of Entrepreneurship and Innovation Management - in press - online 07/2016}

\section{Drivers of growth: the case of French academic spin-off}

Bessière $^{1}$, V.; Gomez-Breysse ${ }^{2}$, M.; Messeghem ${ }^{2}$, K.; Ramaroson $^{2}$, A.; Sammut ${ }^{3}$, S.

1 IAE de Montpellier-Université de Montpellier - MRM / Labex Entreprendre, Place Eugène Bataillon - 34090 MONTPELLIER, France. E-mail: veronique.bessiere@umontpellier.fr 2 AES-Université de Montpellier - MRM/Labex Entreprendre, Avenue Raymond Dugrand 34960 MONTPELLIER, France. E-mail: marie.breysse@umontpellier.fr, karim.messeghem@ umontpellier.fr, andry-haja.ramaroson@ umontpellier.fr

3 ISEM-Université de Montpellier, 208 rue Vendémiaire - 34000 MONTPELLIER, France. Email: sylvie.sammut@umontpellier.fr

This research received a State grant from the Agence Nationale de la Recherche as part of a programme entitled "Investissements d'Avenir" (Ref. ANR-10-LABX-11-01). 


\section{Drivers of growth: the case of French academic spin-off}

\section{Executive summary}

Academic spin-offs (ASOs) have developed considerably in France since the 2000s. However, despite a strong increase in the number of new ventures, little is known about their ability to experience and sustain growth beyond the first five years. Based on a sample of 118 French ASOs from the same generation, this article analyses the factors that determine their growth during the development phase. These factors are derived from a resource-based view $(R B V)$ and a dynamic capabilities approach (DCA). The results of our quantitative study show that four factors determine the growth of ASOs: entrepreneurial orientation (and broader cognitive resources), the acquisition of skills in the entrepreneurial process, the amount of public and private financing, technological capabilities and support programs.

Keywords: Growth - Academic spin-offs - Resources and dynamic capabilities approach Acquisition of skills - Entrepreneurial orientation - Financing - Entrepreneurial support 


\section{Introduction}

Policy makers consider academic spin-offs to be major levers of economic development (Davenport et al., 2002; Lockett et al., 2005; Gisling et al., 2010) and commit significant funds with the goal of obtaining a significant return on their investment (Vincett, 2010). Scholten (2006) demonstrates that academic spin-offs create value by producing more innovative products and services than other technological companies (Blair and Hitchens, 1998) and by expanding more quickly than non-academic start-ups (Shane and Stuart, 2002). Similarly, they contribute to economic growth by creating jobs and generating wealth.

However, many studies have reported that it is difficult for academic spin-offs to grow for three main reasons (Delmar et al., 2003; Macpherson and Holt, 2007; Rasmussen, 2008; Sapienza et al., 2004; Shane, 2004; Geenhuizen and Soetanto, 2009). First, these businesses are generally very young, and the time from invention to innovation to product commercialization is quite long (Lev and Zarowin, 1999; Wright and Stigliani, 2013). Second, spin-offs have to address a range of shareholders' (private sector, institutions, funders and researchers) objectives, all of which have an impact on growth strategies (Clarysse et al., 2005). Third, these businesses often lack resources for product marketing, due in part to the profiles of the entrepreneurs (Vohora et al., 2004). These three factors have a powerful combined effect on business growth, and academic spin-offs often remain very small, given the great complexity of expanding their operations (Mustar et al., 2006; Geenhuizen and Soetanto, 2009; Visintin and Pittino, 2014; Wright et al., 2007). Although the literature indicates that there is increasing interest in academic spin-offs, relatively little is known about how they actually grow (Clarysse et al., 2011; Visintin and Pittino, 2014). The current research focuses on the ability to identify, recognize and exploit the opportunities (Clarysse et al., 2011), the seed capital (Zerbinati et al., 2012), the diversity of skills within teams (Hmieleski and Ensley, 2005) and the influence of entrepreneurial experience (Visintin and Pittino, 2014) that have an impact on growth. However, to our knowledge, few studies have specifically examined the antecedents of growth.

Both the technological potential and the success of these companies, which may be attributed to the commitment of public funds, have raised questions about academic spin-off growth factors (Franzoni and Lissoni, 2009). This article aims to investigate the link between resource endowment and the growth of these companies during their development phases. We therefore 
built a model that integrates the determinants of growth for academic spin-offs, which also allowed us to examine the most relevant resources (Brush et al., 2001; Heirman and Clarysse, 2004; Lockett et al., 200; Mustar et al., 2006; Wright et al., 2007). Moreover, this systemic approach allowed us to study resources as assets and the capacity to develop them according to environment (Lee et al., 2001; Wright et al., 2007). To study our two measures of growth, employment and revenue, we considered both available resources (financing and support) and dynamic capabilities (technological, entrepreneurial orientation, and skills acquisition).

In collaboration with the French Ministry of Higher Education and Research, we conducted an empirical survey of academic spin-offs that were created between 2005 and 2007 and have been supported by academic incubators. Our results show that the determinants (funds raised, skills, entrepreneurial orientation, support and technological capabilities) were positively related to job growth. In addition, skills acquisition and technological capabilities were positively related to revenue growth.

This article is organized into five sections. First, we briefly review the literature on the resourcebased view and present our hypotheses on the relationship between resources and growth. Then, we present our quantitative methodology and our sample. We present our results in the third section, and we discuss these results in relation to the literature in the final two sections.

\section{Conceptual framework and hypotheses}

The literature shows no consensus on the definition of an academic spin-off. The prior research has defined an academic spin-off as a business that is created by one or several members of a public research laboratory to commercialize an innovation (Bigliardi, Galati and Verbano, 2013; McQueen and Wallmark, 1982). Other authors have broadened it, with some noting that academic spin-offs can result from a technology transfer (Matkin, 1990; Steffensen et al., 2000). Others have even defined academic spin-offs as new businesses that commercialize innovations from university research without the inventor necessarily being a part of the project (Nicolaou and Birley, 2003). In any case, these definitions suggest two main categories: pure spin-offs and hybrids (Fryges and Wright, 2014). The first are derived from research projects, which are carried out by a member of a research organization. The latter refers to projects that are related to 
studies that are carried out by a surrogate entrepreneur (Lundqvist, 2014). In this article, we take a broad view and study new businesses that promote university research innovation and are supported by academic incubators. However, ASOs do not constitute a homogenous group of companies (Mustar et al., 2006). Authors have suggested that to compare academic start-ups, which stem from a university or a PRO (parent research organization), and NTBFs (new technology based firm), which are driven by surrogates, we can control the differences between Pure and Hybrid ASOs (Colombo and Piva, 2008). To study the development and the performance of Academic Spin-offs, (O'shea, Chugh and Allen, 2008)) proposed a conceptual framework based on four main theoretical elements: individual characteristics, organizational resources, institutional characteristics and environmental factors. These elements gathered both internal and external resource endowments. Resources can be classified into four broad categories: technological, human, social and financial (e.g., Mustar et al., 2006; Wright et al., 2007). Various studies have shown that academic spin-offs grow only when they have integrated internal and external resources and can use them effectively (Druilhe and Garnsey, 2004; Geenhuizen and Soetanto, 2009). In the last fifteen years, the RBV has come to dominate the literature, addressing the characteristics of both new technology-based businesses and academic spin-offs (Heirman and Clarysse, 2004; Lee et al., 2011; Lockett et al., 2005; Somsuk and Laosirihongthong, 2014).

The RBV is rooted in Penrose's (1959) theory that resources, through their idiosyncratic nature, are vital to an effective growth strategy. This theoretical approach has been applied to studies in strategic management (Wernerfelt, 1984; Barney, 1991, 1997) and entrepreneurship (Foss, 2011). For these authors, the resources that provide a competitive advantage are those tangible or intangible assets that are valuable and not easily imitated or substituted. Although the focus was initially on resources as assets, researchers have more recently stressed the importance of a more dynamic approach in terms of routines and capabilities (Teece et al., 1997). For example, in a rapidly changing environment, it is not the accumulation of resources that makes the difference but rather the dynamic capability to integrate and reconfigure internal and external resources for optimal exploitation. Although academic spin-offs are initially less successful than young technology-based companies in terms of employment, revenue and the capacity for selffinancing and for learning sets them up for better growth in the long run (Ángel Ortín and Vendrell-Herrero, 2014). For Sapienza et al. (2004), 'the race for growth is actually a learning 
race for these young companies' (p. 810). Indeed, efficient learning results in a faster accumulation of resources and thus faster post-creation growth. For this reason, a resource-based view (RBV) provides a suitable theoretical framework to explain the growth of these companies.

Inspired by the works of Barney (1991), Brush et al. (2001), researchers have mobilized several configurations of resources to explain the growth of academic spin-offs. For example, Heirman and Clarysse (2004) focused on physical (technological), financial and human resources, and Wright et al. (2007) suggested that four resources should be considered: technological, financial, human and social.

\subsection{Financial resources}

The term financial resources is used to refer to both the amount and the nature of funding. Zerbinati, Souitaris and Moray (2012) demonstrated the crucial role of seed capital in spin-off growth. The ability to raise capital from the very start depends on both a firm's resources (technological field and ability to sell) and its social context (incubation model, type of technology transfer, and researcher's investment in the project). Raising capital helps a new business to build forward momentum.

A positive relationship was observed between financing and the growth of young companies (Cooper et al., 1994). The literature on venture capital highlights the importance of funding in new venture success (Stéphany, 2015). With sufficient funds, a company can invest in recruitment, technology, its organization, and other resources, thereby reducing the risk of failure (Brüderl and Schussler, 1990; Shane and Stuart, 2002; Zerbinati et al., 2012). Therefore, we hypothesize that:

H1: The amount of funding that is raised by academic spin-offs is positively related to their growth.

\subsection{Human Resources: Skills acquisition}

Human resources are the accumulated skills of a company's founders, its management team and staff (Lundqvist, 2014; Wright et al., 2007; Zhao et al., 2013). Three components of the specific human capital of founders are underscored in the literature, business administration and entrepreneurial skills, experience in a given sector and the capabilities to move from research to 
invention (Criaco et al., 2014). The prior research emphasizes that resource endowments, such as skills, determine the potential growth of young companies (Unger et al., 2011; Zhao, Song and Storm, 2013). Academic spin-offs need to complement their internal and external resources with additional skills (Rasmussen et al., 2011). Scholars argue that ASOs suffer from a homogeneity of resources during their proof of viability phase and establish a positive link between survival and team heterogeneity (Aspelund et al., 2005; Zahra et al., 2009). Authors have called for further investigation on skills acquisition in academic spin-offs, and their performance has often been found to be limited by a lack of skills (Sapienza et al., 2004).

It has been difficult to identify the set of skills that influence growth, as noted in studies on business skills and academic entrepreneurship (Di Gregorio and Shane, 2003; Heirman and Clarysse, 2004; Lockett and Wright, 2005). According to the literature, the entrepreneurial skills that are needed to develop a business have been addressed in terms of tangible (financial, human, technological, organizational) and intangible resources (employees, interactions between firm members, decision-making, and culture) (Brush and Lichtenstein, 2001; Clarysse and Moray, 2004; Cooper et al., 1994). Vohora et al. (2004) noted the skills that are often lacking in academic spin-offs, including marketing, management and international. Various authors have noted that these skills, whether entrepreneurial or managerial, determine the potential growth of young companies (Unger et al., 2011; Zhao et al., 2013). Therefore, we hypothesize that their acquisition is linked to growth.

\section{H2: The skills that are acquired by academic spin-offs are positively related to their growth.}

\subsection{Technological capabilities}

In addition to financial and human resources, Lee et al. (2011) underscored the importance of two dynamic capabilities: technological capabilities and entrepreneurial orientation. In their seminal work, Teece et al. (1997) demonstrated that dynamic capabilities are a key factor in firm

performance, without which resources cannot be transformed into competitive advantage (Zollo and Winter, 2002; Zott, 2003). Dynamic capabilities have been defined as 'the firm's ability to integrate, build, and reconfigure internal and external competences to address rapidly changing environments' (Teece et al., 1997, p. 516). Most of the studies have focused on young innovative businesses in which technological development plays a major role. After this phase, the ability to 
market a new product becomes far more decisive, as highlighted by studies on 'the valley of death' (Markham, 2002; Markham et al., 2010). According to Wright and Stigliani (2013), this seems to reflect a shift from a logic of exploration to exploitation: 'Entrepreneurial firms may need to develop capabilities and resources to switch from one growth mode to another over the life cycle of the firm: for example, having grown initially in terms of building the value of a technology, they may need to build capabilities to generate revenue. This may involve a shift from exploration-only skills to exploitation skills, as well as a need to acquire or otherwise access downstream complementary assets' (p. 12).

From this perspective, technological capabilities refer to the ability to identify an invention, develop it technologically, and commercialize it as a product to meet a market need (Berkhout, et al., 2010). Lee et al. (2011) added that the definition also includes a company's ability to achieve a sustainable competitive advantage from its technological knowledge, the creation of specific and inimitable skills, and the capabilities that are protected by intellectual property (e.g., patents). Technological innovation can become a lever for profitability (Hsu, 2014) and may be seen as a better investment opportunity (Chemmanur and Fulghieri, 1999). In line with this, studies have shown the importance of bringing innovative products to the market to survive and sustain growth (Datta et al., 2014; Lin et al., 2006). Therefore, we hypothesize that:

\section{H3: The technological capabilities of academic spin-offs are positively related to their growth.}

\subsection{Entrepreneurial orientation}

The concept of entrepreneurial orientation has been attributed to Miller (1983), who used the term to refer to the entrepreneurial strategies of existing businesses. This concept has been widely used in the literature on entrepreneurship and strategic management (Basso et al., 2009; Covin and Lumpkin, 2011). According to Lee et al. (2001), entrepreneurial orientation is an organizational resource for gaining competitive advantage. It reflects the ability of a company to be innovative, proactive and risk-taking (Covin and Slevin, 1991; Miller, 1983). Many studies have tried to link entrepreneurial orientation to performance and growth (Rauch et al., 2009) and, generally, companies that are characterized by strong growth also demonstrate a strong entrepreneurial orientation (Moreno and Casillas, 2008; Stevenson and Jarillo, 1990). Lumpkin and Dess (2001) highlighted the effects of entrepreneurial orientation on several performance 
factors, including growth. Other authors, however, have reported no significant relationship (Covin and Slevin, 1991), particularly in the case of academic spin-offs (Walter, Auer and Ritter, 2006). Therefore, we hypothesize that:

H4: The entrepreneurial orientation of academic spin-offs is positively related to their growth.

\subsection{Social Resources: Support}

The social capital of entrepreneurial teams plays a decisive role in the growth of academic spinoffs (Lee et al., 2001; Vohora et al., 2004). According to Mosey and Wright (2007), social capital can vary greatly, depending on past entrepreneurial experience. For this reason, entrepreneurial support services are crucial for building and strengthening social capital (Lee et al., 2001; Rasmussen et al., 2011), especially by providing access to networks (Hackett and Dilts, 2004; Lin et al.,2006; Smilor, 1987). Belonging to professional networks can facilitate access to new resources, thereby contributing to growth. In fact, over the years, many studies have amply demonstrated the positive influence of incubator support services on the growth of spin-offs (Mustar et al., 2006; Phan et al., 2005; Rasmussen et al., 2011).

H5: The entrepreneurial support of academic spin-offs is positively related to their growth.

\section{Data and method}

To test our hypotheses, we used data from two samples of French academic spin-offs, one that was centred on job growth and the other on revenue growth. We used linear regression to model the relationship between the explanatory variables and the growth indicators. The relationship between growth and its determinants can be described by the following equation:

$$
\begin{aligned}
\text { Growth }=\alpha+ & \beta_{1} * \text { Finance }+\beta_{2} * \text { Skills Acquisition } \\
& +\beta_{3} * \text { Technological Capabilities }+\beta_{4} * \text { Entrepreneurial Orientation } \\
& +\beta_{5} * \text { Support }+\varepsilon
\end{aligned}
$$

where $\alpha$ is a constant, $\beta_{n}$ are the coefficients to be estimated, and $\varepsilon$ is the error term. 


\subsection{Sample}

The objective was to examine the drivers of growth in academic spin-offs during their development phase, which is considered to be the proof of a viability phase (Vanaelst et al., 2006), and has been described as the 'valley of death' in the literature (Markham et al., 2010). In France, ASOs are supported by academic incubators. The French support ecosystem is characterized by a diversity of actors and structures at regional (CCI, Pépite, Pépinieres, incubateurs, SATT, Pôle de compétitivité) and national levels (BPI, AVISE, ANR ${ }^{1}$ ). At the territorial level, we have a specific combination of these national and regional structures. Among them, some are generalists and others are specialists. In this context, academic incubators were created in each French region in 1999 and are dedicated to the creation of academic spin-offs. In fifteen years, academic incubators have supported more than 4000 companies. In our study, we focused on the generation of companies that were created between 2005 and 2007, and a study was conducted in 2013 in partnership with the French Ministry of Higher Education and Research for the period from 2009 to 2012. The population is comprised of 557 companies that are supported by academic incubators in France that exist within different environments and belong to a range of support structures. At the time of the study, the academic spin-offs were between five and seven years old and were selected to ensure the homogeneity of the sample.

As part of an observatory of entrepreneur-researchers, our team explored several themes: motivation and personality traits, skills, entrepreneurial orientation, innovation, funding and support. In a preliminary regional study that was conducted in 2012 in partnership with the Languedoc-Roussillon Incubation, we tested the measurement scales that had been previously validated for entrepreneurship; if necessary, we built our own scales based on ten case studies and in-depth interviews with the top management of these companies. This survey was pre-tested by 30 individuals to ensure clarity for the potential respondents. The data were first collected at the regional level and then at the national level.

The surveys were available online through an email that was sent to all of the entrepreneurs. To ensure an optimal response rate, we first contacted every entrepreneur by telephone to inform

\footnotetext{
${ }^{1}$ A detailed explanation of each structure is provided in the appendix 1
} 
them of the study's objectives and to encourage them to complete the survey. The investigation was closed in December 2013 with 206 returns, for an overall response rate of 37\%. Table 1 shows that the sample is representative of the population, with the exception of firms that are in a situation of cessation. This result is explained by the difficulty of contacting entrepreneurs whose businesses are no longer active. Due to the missing data, the study on job growth included 149 companies, and the study on sales growth included 118 companies. For the job growth sample, the average number of jobs was 7.19, with a median of 5 , a minimum of 1 , and a maximum of 44. For the revenue growth sample, the average revenue was $370,000 €$, with minimum and maximum values of 6,000€ and 2,722,000€, respectively, and a median value of 270,000€ (Table 2).

\section{Table 1. Sample description}

\section{Table 2. Company size at the time of the survey}

\subsection{Growth measures}

Business growth is a complex multifactor phenomenon (Boissin et al., 2009). The most common measures are the changes in the number of jobs that are created and revenue (Mustar et al., 2008; Shane and Stuart, 2002). In this study, we used these measures as they are often used in entrepreneurship research. Job growth was measured by the ratio of the number of full-time employees in 2012 to company age (Zerbinati et al., 2012). The distribution of the ratio values was not normal; thus, they were log-transformed to meet the assumptions of our statistical tests. The second measure was revenue growth in absolute terms, which was in line with most of the studies on SMEs and entrepreneurship (Coad and Hölzl, 2010). Over one year, the absolute value of revenue growth was the difference between the revenue of the current year and that of the previous year. We then log-transformed these values. To exceed the limit of a growth indicator in a single year, we took into account the mean growth over the three successive years. Additionally, note that the correlation between job growth and mean revenue growth was 0.61 ( $p$ $=0.000$ ). 


\subsection{Explanatory variables}

\section{Financing}

One of the measures that are used in financing studies is the amount of funding that is raised by young companies (Cooper et al., 1994). We therefore took into account the cumulative amount of funds that had been raised since the creation of the spin-offs, and this covered five or seven years for the companies in this study. The companies in the job growth sample raised a mean of $240,000 €$, with a standard deviation of $440,000 €$. For the revenue growth sample, the mean was $170,000 €$ raised, with a standard deviation of $230,000 €$. The median was $80,000 €$ for both samples and the maximum was 3,150,000€ for the job growth sample and 1,250,000€ for the revenue sample.

\section{Skills acquisition}

We also studied the acquisitions of skills in the following areas: management, marketing and international business (Vanaelst et al., 2006; Vohora et al., 2004). For each of the three areas, the respondents were asked about skills acquisition by three modes: recruitment, training, or new partners. The score could thus vary from 0 to 3 . A value of 0 corresponded to no skills acquired in an area, and a score of 3 indicated that the company used the three modes of acquisition.

\section{Technological capabilities}

In line with previous work, we measured the technological capabilities by the number of patents (Acs et al., 2002; Covin and Slevin, 1991; Griliches, 1990; Guan and Yam, 2015). A full 50\% of the companies had not filed any patents, and the maximum was 12 for the job growth sample and 7 for the sales growth sample. The median number of patents was 0 and 2, respectively. 


\section{Entrepreneurial orientation}

To assess entrepreneurial orientation, we used the 5-point Likert scale that was proposed by Covin and Slevin (1991), which is composed of 9 items. The Cronbach's alpha for item reliability was 0.75 . We used a confirmatory factor analysis to assess the properties of the scale. The chi2 test (Chi2 $(23)=18.95 ; \mathrm{p}=0.70)$ indicated a good fit of the theoretical model to the empirical data. The comparative fit index (CFI, 1.00) was above the threshold of 0.90. The root mean square error of approximation (RMSEA) of 0.00 and the standardized residual root mean square (SRMR) of 0.03 were both below the threshold of 0.08 (Hu and Bentler, 1999). The links between the indicators and the construct of entrepreneurial orientation were all significant at $\mathrm{p}=$ 0.000. The internal consistency reliability (rho 0.71) was slightly higher than the threshold of 0.70 (Fornell and Larcker, 1981). Given these values, we used the factor score for entrepreneurial orientation as an explanatory variable in the regression models.

\section{Support}

Academic incubators are designed to support new ventures with research-based innovations. This is formalized either through support for a technology transfer to a project team (an entrepreneurial team that is already in place or that has been created by the incubator) or through support to the researcher for business creation. In either case, high-potential projects are targeted. The support staff focuses on entrepreneurship, networking, financing, logistics (e.g., locale and equipment) and business management focuses on structure and development projects. The literature suggests that regardless of the nature of the support, the social capital that is generated promotes the growth of academic spin-offs (Lee et al., 2001). In this study, we measured support as either 1 for incubator support or 0 for no support in the last three years. We did not, however, distinguish between the types of support.

\subsection{Control variables}


Consistent with previous studies, we controlled for differences between the sectors (e.g., Zerbinati, et al., 2012). We thus incorporated three binary variables into the model to designate the sectors (ICT, industry and biotechnology). The services sector was selected as the reference. In addition, as our samples were composed of both pure and hybrid academic spin-offs, we attributed a value of 1 to companies from research (pure) and 0 to research-related companies (hybrid).

Table 3 provides a summary of our variables, and the correlation matrix between the variables is presented in the Appendix. The tests revealed that our variables showed no multicollinearity (mean VIF: job growth sample $=1.41$; revenue growth sample: 1.41 ).

\section{Table 3. Descriptive statistics of the explanatory variables}

\section{Results: Growth determinants}

To analyze the relationships between growth and the explanatory variables, we used a hierarchical regression. First, we introduced the control variables into the model. Then, we integrated the explanatory variables. The two complete models were significant (Table 4). We observed a $32 \%$ increase in the variance explained when we introduced the explanatory variables $(\mathrm{p}=0.000)$ for job growth and a $13 \%$ increase $(\mathrm{p}=0.011)$ for mean revenue growth. We conducted specification, heteroscedasticity and residual normality tests to confirm the validity of the estimates.

The first hypothesis, that the amount of financing raised by academic spin-offs would be positively related to growth, was validated for job growth $(\beta=0.333, \mathrm{p}<0.05)$ but not for revenue growth. Second, our results indicated a positive relationship between acquisition of marketing skills and job growth $(\beta=0.282 ; \mathrm{p}<0.05)$ and revenue growth $(\beta=0.356, \mathrm{p}<0.05)$, but this was not the case for management skills and international experience. The third

hypothesis was that the technological capabilities of the academic spin-offs would have a positive relationship with growth. Our results showed that the two growth measures increased with the number of patents, which was an indicator of technological capability. The hypothesis was validated for job growth $(\beta=0.077 ; \mathrm{p}<0.05)$ and revenue growth $(\beta=0.135, \mathrm{p}<0.01)$. Table 4 shows that entrepreneurial orientation had a positive relationship with job growth $(\beta=$ 
0.361, $\mathrm{p}<0.05)$, but the relationship with revenue growth was not significant. Our fourth hypothesis was thus only partially validated. Hypothesis 5, that entrepreneurial support to academic spin-offs would have a positive relationship with growth, was validated for job growth with a significant relationship $(\beta=0.583, \mathrm{p}<0.01)$, but not for revenue growth.

In addition, it should be noted that the sectors differed significantly for job growth. Growth was lower in industry $(\beta=-0.496, \mathrm{p}<0.05)$ and biotechnology $(\beta=-0.585, \mathrm{p}<0.001)$ than in the service sector. Conversely, there was no significant difference between ICT and the service sector. Revenue growth was $10 \%$ lower in the biotechnology sector than in the service sector $(\beta$ $=-0.479, \mathrm{p}<0.10)$, but there was no significant difference for the other two sectors. The difference between the two types of academic spin-offs, pure and hybrid, was not significant.

In summary, for job growth, skills acquisition contributed most to the variance that was explained by the model $\left(\Delta \mathrm{R}^{2}=17 \%, \mathrm{p}=0.000\right)$, followed by the amount of funds raised $\left(\Delta \mathrm{R}^{2}=\right.$ $5 \% ; \mathrm{p}=0.005)$, technological capabilities $\left(\Delta \mathrm{R}^{2}=5 \% ; \mathrm{p}=0.003\right)$, support $\left(\Delta \mathrm{R}^{2}=4 \% ; \mathrm{p}=0.004\right)$ and entrepreneurial orientation $\left(\Delta \mathrm{R}^{2}=2 \% ; \mathrm{p}=0.038\right)$. For revenue growth, the acquisition of marketing skills contributed most to the variance that was explained by the model $\left(\Delta R^{2}=5 \% ; p\right.$ $=0.003)$, followed by technological capabilities $\left(\Delta R^{2}=3 \% ; p=0.032\right)$. The other variables had no significant relationship to growth.

Table 4 also shows that the predictive ability of the job growth model (adjusted $\mathrm{R}^{2}=29 \%$ ) was higher than that of the revenue growth model (adjusted $\mathrm{R}^{2}=11 \%$ ). This indicates that the growth determinants - funding, skills, technological capabilities, entrepreneurial orientation and support - had a greater combined effect on job creation than on revenues for the companies five to seven years after creation. For new technology-based businesses, one explanation may be that job creation advances more quickly than sales because of the relatively long period that is needed to bring a product to market (Brush et al., 2001; Delmar et al., 2003).

Baum and Silverman (2004) studied the impact of venture capitalists on the performance of innovative young companies, and Bruneel et al., (2012) analysed the performance of spin-offs based on typology. No other study, to our knowledge, took into account a range of resources and 
included the two variables, employment and revenue, to explain the growth of academic spinoffs. We thus present for the first time the results for two measures of growth in a relatively homogeneous type of business (academic spin-offs) of the same generation. The resources were all positively related to job growth, whereas technological capability was mainly related to revenue growth. These results suggest that an overall resource-based approach explains job growth more directly than activity sector in the case of academic spin-offs.

\section{Table 4. Summary of the linear regression results}

\section{Discussion}

This study of spin-offs that are supported by academic incubators shows that the amount of funds that are raised, the acquisition of skills, technological capabilities and support services are factors of growth for these businesses. The results have both theoretical and managerial implications.

Studies have shown that financing is fundamental to startup performance, especially the funding from venture capitalists or angel investors (Stéphany, 2015). Our study took into account all financing sources, including the public sector, thus extending earlier works on entrepreneurial financing. We confirmed the positive relationship between financing and growth, but only for growth in employment. No relationship was observed between the amount of financing (from the time of business creation) and revenue growth in the $5^{\text {th }}, 6^{\text {th }}$ and $7^{\text {th }}$ years of business operations. One of the explanations has to do with the nature of academic spin-offs, as the phase of R\&D is often very long and capital is often used for investments rather than commercial development. These findings are in line with the reports in the literature. Kerr et al. (2014) showed a positive impact of funding by angel investors on employment in the four to nine years following an investment, which is a relatively long term and not so different from our findings.

Our work highlights the positive relationship between the acquisition of skills and growth. The results especially confirm the importance of acquiring marketing skills, both for job growth and revenue growth. In contrast to the previous results (Clarysse and Moray, 2004; Vanaelst et al., 2006; Vohora, Wright and Lockett, 2004), however, acquiring management skills or international experience had no significant relationship with either growth indicator. Thus, acquiring marketing skills helped to overcome obstacles to job and revenue growth 
independently of how the skills were acquired (Brush and Lichtenstein, 2001; Rasmussen, Mosey and Wright, 2011; Zott and Huy, 2007).

Our results for technological capabilities confirmed those of Lin et al. (2006) and Datta, et al. (2014), who noted the importance of bringing an innovation to market as a means of ensuring survival and sustainable growth. In addition, the results show that technological capabilities were positively related to growth in both employment and revenue. In line with Zahra and Nielsen (2002), we observed that the ability to bring an innovative product to market was a key to the economic growth and development of academic spin-offs. This had less to do with technological resources and far more to do with the ability to adapt to changing markets and the willingness to engage in continuous learning (Ortín-Ángel and Vendrell-Herrero, 2014).

Rauch et al. (2009) observed that entrepreneurial orientation generates higher performance. Others have suggested that entrepreneurial orientation is related to performance in terms of increased profits, growth and non-financial criteria, such as shareholder satisfaction (Lumpkin and Dess, 2001). Nevertheless, in the case of academic spin-offs, Walter et al. (2006) showed that although entrepreneurial orientation is important to attract customers and develop relational capital, it has no direct effect on growth. Our results confirm these studies and extend them by bringing a temporal dimension to the literature. Indeed, we show that entrepreneurial orientation has no direct link with the growth of academic spin-offs in the key development phase of five to seven years, which has been described as the 'valley of death'.

Our research also confirms the positive impact of support on the growth of academic spin-offs (Lee, Lee and Pennings, 2001; Rasmussen, Mosey and Wright, 2011). However, this relationship is only partial, as the impact was positive on job growth, but support had no significant impact on revenue growth. These results are consistent with those of Pena (2004), who showed that support contributes positively to job growth in incubated companies, but not to revenue growth.

In summary, our work is in line with the works of Lev and Zarowin (1999) and Wright and Stigliani (2013), who explained this partial link in the slow development of academic spin-offs. Getting from research to invention, to innovation, and finally to bringing a product to the market takes time. It requires early hiring although revenue flow has not yet begun. This explains the significant relationship between support and job growth but not revenue growth. This result 
nevertheless should be further explored by taking into account differences in sectors. Last, this study demonstrates the power of the resource-based view to explain job growth more than revenue growth for academic spin-offs between five and seven years.

\section{Contributions and limitations}

Our findings contribute to the theory in several ways. First, they show that a framework that encompasses the resource-based view and the concept of dynamic capabilities is well-suited to assess the factors of success in innovative firms and, more specifically, to examine the determinants of growth in academic spin-offs (Heirman and Clarysse, 2004; Lee, Lee and Pennings, 2001; Lockett and Wright, 2005; Somsuk and Laosirihongthong, 2014).

Second, this study provides a response to the observation that few studies have sought to identify the set of skills that facilitate the growth of these businesses (Di Gregorio and Shane, 2003; Heirman and Clarysse, 2004; Lockett and Wright, 2005). For example, good marketing skills emerged as a notable growth factor.

Third, our work also confirms the value of an approach that combines a resource-based view and dynamic capabilities (Lee, Lee and Pennings, 2001; Wright, 2007). We found that the businesses that showed the greatest growth were those that not only built up their human and financial resources but also deployed their technological capabilities and acquired the skills that were needed to maintain their position.

This research also responds to the call of Rasmussen, Mosey and Wright (2007) to consider skills acquisition in the development of spin-offs. In line with Wright and Stigliani (2013), we show that although technological innovation is important, marketing and managerial skills, financing, and support strengthen the potential of spin-offs and help them to move from the logic of exploration to the logic of exploitation.

From a managerial perspective, our results encourage national and regional policies that enhance support for these companies and confirm the works of Gilsing et al. (2010) and Lockett et al. (2005). Public policies need to take into account the importance of (i) business-oriented skills for entrepreneurial success and (ii) public-private partnerships for adequate support to growthoriented academic spin-offs. 
Our results should thus encourage academic entrepreneurs to ask themselves serious questions about their ability to acquire needed resources (according to what plans and what modes) (Rasmussen, Mosey and Wright, 2011), their choice of networks (what type of partners, what type of support), and their financing.

Finally, our results highlight the key roles of marketing skills and technological capabilities in revenue growth that should help guide entrepreneurs in their investments. However, we note that the number of patents as a measure of technological capabilities (Griliches, 1990) takes only codified knowledge into account. Thus, this measure should be expanded in future studies with the inclusion of indicators of company skills and knowledge that are not subject to patent protection to better understand the complexity of technological capabilities. Finally, within the specific context of French ecosystem support, further investigation could integrate the contingency role of the territorial actors in combination with an ASO performance analysis.

\section{Conclusion}

This article highlights how resources and dynamic capabilities contribute to the growth of academic spin-offs, especially in the 'valley of death'. Although studies have tended to focus on a single type of resource, we took a comprehensive approach and showed how factors such as financing, skills acquisition, technological capabilities, support and, to a lesser extent, entrepreneurial orientation contribute to the growth of academic spin-offs.

We examined growth in terms of both employment and revenue. Generally, the factors contributed more to job growth than to revenue growth, perhaps because of the type of business and the period upon which we focused. Our results suggest two major research perspectives. First, although our results show that the acquisition of marketing skills contributes to the growth of academic spin-offs, they do not indicate the best way to acquire these skills. As Rasmussen et al. (2011) suggested, it now seems important to determine the best way to gain these skills. Should priority be given to recruitment, training or outside consultants? Second, the performance of academic spin-offs was assessed in terms of job and revenue growth. The literature highlights the difficulty of assessing the profitability of these companies (Vincett, 2010). It would thus be interesting to investigate the relationships between the resources and dynamic capabilities of academic spin-offs and their financial performance by enriching the selected measures. 


\section{$\underline{\text { Tables }}$}

Table 1. Sample description

\begin{tabular}{llllllll}
\hline & & Population & \multicolumn{2}{c}{$\begin{array}{l}\text { Sample } \\
\text { (employment) }\end{array}$} & $\begin{array}{l}\text { Sample } \\
\text { (revenue) }\end{array}$ \\
\hline \multirow{3}{*}{ Year established } & & Freq. & $\%$ & Freq. & \% & Freq. $\%$ \\
& 2005 & 202 & $36 \%$ & 43 & $29 \%$ & 35 & $30 \%$ \\
& 2006 & 155 & $28 \%$ & 52 & $35 \%$ & 40 & $34 \%$ \\
& 2007 & 198 & $36 \%$ & 54 & $36 \%$ & 43 & $36 \%$ \\
\hline \multirow{2}{*}{ Type of ASOs } & Pure* & 204 & $37 \%$ & 60 & $40 \%$ & 49 & $42 \%$ \\
& Hybrid* & 351 & $63 \%$ & 89 & $60 \%$ & 69 & $58 \%$ \\
\hline \multirow{3}{*}{ Activity sector } & Biotechnology & 134 & $24 \%$ & 49 & $33 \%$ & 38 & $32 \%$ \\
& Industry & 81 & $15 \%$ & 24 & $16 \%$ & 22 & $18 \%$ \\
& Services & 168 & $30 \%$ & 35 & $23 \%$ & 29 & $25 \%$ \\
& ICT & 172 & $31 \%$ & 41 & $28 \%$ & 29 & $25 \%$ \\
\hline \multirow{2}{*}{ Situation in 2012 } & In business & 433 & $78 \%$ & 149 & $100 \%$ & 118 & $100 \%$ \\
& No longer exists & 122 & $22 \%$ & & - & & - \\
\hline Overall & & 555 & & 149 & & 118 & \\
\hline
\end{tabular}

* Pure: entrepreneur was a member of the research organization

* Hybrid: entrepreneur is a surrogate for the researcher

Table 2. Company size at the time of the survey

\begin{tabular}{lcccc}
\hline & Number of jobs & & \multicolumn{2}{c}{$\begin{array}{c}\text { Mean revenue * } \\
(\mathbf{2 0 1 0 - 2 0 1 2})\end{array}$} \\
\hline & Population & $\begin{array}{c}\text { Sample: } \\
\text { employment }\end{array}$ & Population & Sample: revenue \\
\hline $\mathrm{N}$ & 270 & 149 & 359 & 118 \\
Mean & 9.75 & 7.19 & 528 & 370 \\
Standard deviation & 18.64 & 7.3 & 1273 & 445 \\
Minimum & 0 & 1 & 0 & 6 \\
$1^{\text {st }}$ quartile & 2 & 3 & 67 & 125 \\
Median & 5 & 5 & 197 & 217 \\
$3^{\text {rd }}$ quartile & 10 & 9 & 481 & 424 \\
Maximum & 206 & 44 & 14172 & 2722 \\
\hline
\end{tabular}

* In thousands of euros 


\section{Table 3. Descriptive statistics of the explanatory variables}

\begin{tabular}{lccccc}
\hline Job growth (N = 149) & Mean & SD & Min. & Median & Max. \\
\hline No. of jobs/age (Zerbinati et al. 2012) & 1.20 & 1.15 & 0.14 & 0.83 & 6.83 \\
Amount of funds raised * & 240 & 440 & 0 & 80 & 3150 \\
Management skills acquired & 0.63 & 0.68 & 0 & 1 & 3 \\
Marketing skills acquired & 0.68 & 0.68 & 0 & 1 & 3 \\
International skills acquired & 0.36 & 0.57 & 0 & 0 & 3 \\
Technological capabilities & 1.36 & 2.11 & 0 & 0 & 12 \\
Entrepreneurial orientation & 0.02 & 0.40 & -1.30 & 0.06 & 0.77 \\
Support & 0.88 & - & 0 & 1 & 1 \\
\hline & & & & & \\
\hline Revenue (N = 118) & Average & SD & Min. & Median & Max. \\
\hline Revenue growth (in k€) & 69 & 3 & 7 & 81 & 854 \\
Amount of funds raised * (in k€) & 170 & 230 & 0 & 80 & 1250 \\
Management skills acquired & 0.62 & 0.65 & 0 & 1 & 3 \\
Marketing skills acquired & 0.68 & 0.67 & 0 & 1 & 2 \\
International skills acquired & 0.33 & 0.51 & 0 & 0 & 2 \\
Technological capabilities & 1.31 & 1.77 & 0 & 0.50 & 7 \\
Entrepreneurial orientation & 0.01 & 0.40 & -1.30 & 0.06 & 0.70 \\
Support & 0.87 & - & 0 & 1 & 1 \\
\hline
\end{tabular}


Table 4. Summary of the linear regression results

\begin{tabular}{|c|c|c|c|c|}
\hline & \multicolumn{2}{|c|}{ Job growth } & \multicolumn{2}{|c|}{ Revenue growth } \\
\hline & $\begin{array}{c}\text { Control } \\
\text { variables }\end{array}$ & Full model & $\begin{array}{c}\text { Control } \\
\text { variables }\end{array}$ & Full model \\
\hline $\mathrm{N}$ & 149 & 149 & 118 & 118 \\
\hline \multirow{2}{*}{ Control variables } & $\boldsymbol{\beta}$ & $\bar{\beta}$ & $\beta$ & $\boldsymbol{\beta}$ \\
\hline & $\mathrm{t}$ & $\mathbf{t}$ & $\mathbf{t}$ & $\mathrm{t}$ \\
\hline \multirow[t]{2}{*}{ Industry } & -0.114 & $-0.496^{*}$ & 0.183 & 0.045 \\
\hline & -0.470 & -2.370 & 0.710 & 0.170 \\
\hline \multirow[t]{2}{*}{ Biotechnology } & -0.250 & $-0.585 * *$ & -0.419 & $-0.479+$ \\
\hline & -1.230 & -3.300 & -1.510 & -1.87 \\
\hline \multirow[t]{2}{*}{ ITC } & 0.058 & -0.213 & 0.077 & 0.124 \\
\hline & 0.270 & -1.140 & 0.280 & 0.450 \\
\hline \multirow[t]{2}{*}{ Pure ASOs (vs hybrid) } & 0.018 & -0.160 & 0.053 & 0.037 \\
\hline & 0.110 & -1.190 & 0.260 & 0.180 \\
\hline \multicolumn{5}{|l|}{ Explanatory variables } \\
\hline \multirow[t]{2}{*}{ Amount of funds raised } & & $0.333^{*}$ & & 0.053 \\
\hline & & 2.300 & & 0.120 \\
\hline \multirow[t]{2}{*}{ Management skills acquired } & & 0.154 & & -0.137 \\
\hline & & 1.330 & & -0.760 \\
\hline \multirow[t]{2}{*}{ Marketing skills acquired } & & $0.282 *$ & & $0.356^{*}$ \\
\hline & & 2.260 & & 2.150 \\
\hline \multirow[t]{2}{*}{ International skills acquired } & & 0.205 & & -0.186 \\
\hline & & 1.590 & & -0.930 \\
\hline \multirow[t]{2}{*}{ Technological capabilities } & & $0.077 *$ & & $0.135 * *$ \\
\hline & & 2.320 & & 2.780 \\
\hline \multirow[t]{2}{*}{ Entrepreneurial orientation } & & $0.361 *$ & & 0.301 \\
\hline & & 2.240 & & 1.170 \\
\hline \multirow[t]{2}{*}{ Support } & & $0.583 * *$ & & 0.408 \\
\hline & & 2.910 & & 1.220 \\
\hline \multirow{2}{*}{ Constant } & -0.122 & $-0.872 * * *$ & $4.302 * * *$ & $3.702 * * *$ \\
\hline & -0.740 & -4.220 & 20.870 & 10.850 \\
\hline $\mathrm{R}^{2}$ & $2 \%$ & $34 \%$ & $6 \%$ & $19 \%$ \\
\hline
\end{tabular}




\section{Appendices}

\section{Appendix 1. Glossary}

CCI, Chambres de commerce et d'industrie

Pépite, Pôle étudiant pour l'innovation, le transfert et l'entrepreneuriat

Pépinieres, support structure which host the companies

Incubateurs, support structure to help companies in their creation process

SATT, Société d'accélération de transfert de technologie

Pôle de compétitivité, Group of public (institutional, support structure) and private actors (companies, network) of a field created to develop innovative projects to a market.

BPI, Banque publique d'investissement

AVISE, Agence de valorisation de l'innovation sociale et de l'entreprise

ANR, Agence nationale de la recherche

Appendix 2. Correlation matrix for the job growth sample $(\mathrm{N}=118)$

\begin{tabular}{|c|c|c|c|c|c|c|c|c|c|c|c|c|c|c|}
\hline & Variables & 1 & 2 & 3 & 4 & 5 & 6 & 7 & 8 & 9 & 10 & 11 & 12 & 13 \\
\hline 1 & Job growth & 1 & & & & & & & & & & & & \\
\hline 2 & Biotechnology & -0.13 & 1 & & & & & & & & & & & \\
\hline 3 & Industry & -0.02 & $-0.31 *$ & 1 & & & & & & & & & & \\
\hline 4 & Service & 0.05 & $-0.39 *$ & $-0.24^{*}$ & 1 & & & & & & & & & \\
\hline 5 & ITC & 0.10 & $-0.43 *$ & $-0.27 *$ & $-0.34 *$ & 1 & & & & & & & & \\
\hline 6 & Pure ASOs (vs hybrid) & -0.02 & $0.24 *$ & -0.10 & 0.00 & $-0.17 *$ & 1 & & & & & & & \\
\hline 7 & Amount of funds raised & $0.21 *$ & 0.08 & 0.02 & -0.06 & -0.04 & 0.05 & 1 & & & & & & \\
\hline 8 & Management skills acquired & $0.30 *$ & 0.13 & 0.00 & -0.14 & 0.00 & $0.21 *$ & 0.05 & 1 & & & & & \\
\hline 9 & Marketing skills acquired & $0.36^{*}$ & 0.01 & 0.04 & -0.12 & 0.07 & 0.12 & 0.03 & $0.58 *$ & 1 & & & & \\
\hline 10 & International skills acquired & $0.29 *$ & 0.06 & 0.07 & $-0.19 *$ & 0.06 & 0.13 & 0.06 & $0.29 *$ & $0.49 *$ & 1 & & & \\
\hline 11 & Technological capabilities & $0.23 *$ & $0.25^{*}$ & 0.11 & -0.07 & $-0.29 *$ & 0.14 & 0.14 & 0.14 & 0.10 & $0.18^{*}$ & 1 & & \\
\hline 12 & Entrepreneurial orientation & $0.23 *$ & -0.05 & 0.03 & -0.09 & 0.11 & 0.00 & 0.09 & 0.04 & 0.03 & 0.04 & $0.19 *$ & 1 & \\
\hline 13 & Support & $0.25 *$ & 0.08 & 0.05 & $-0.23 *$ & 0.09 & 0.01 & 0.10 & $0.16^{*}$ & 0.07 & 0.09 & 0.10 & 0.02 & 1 \\
\hline
\end{tabular}


Appendix 3. Correlation matrix for the revenue growth sample $(\mathrm{N}=118)$

\begin{tabular}{|c|c|c|c|c|c|c|c|c|c|c|c|c|c|c|}
\hline & Variables & 1 & 2 & 3 & 4 & 5 & 6 & 7 & 8 & 9 & 10 & 11 & 12 & 13 \\
\hline 1 & Revenue growth & 1 & & & & & & & & & & & & \\
\hline 2 & Biotechnology & $-0.23 *$ & 1 & & & & & & & & & & & \\
\hline 3 & Industry & 0.13 & $-0.33^{*}$ & 1 & & & & & & & & & & \\
\hline 4 & Services & 0.05 & $-0.39 *$ & $-0.27 *$ & 1 & & & & & & & & & \\
\hline 5 & ITC & 0.09 & $-0.39 *$ & $-0.27 *$ & $-0.33 *$ & 1 & & & & & & & & \\
\hline 6 & Pure ASOs (vs hybrid) & -0.04 & $0.27 *$ & -0.09 & -0.04 & -0.16 & 1 & & & & & & & \\
\hline 7 & Amount of funds raised & 0.15 & -0.17 & $0.20 *$ & 0.02 & -0.02 & 0.1 & 1 & & & & & & \\
\hline 8 & Management skills acquired & 0.06 & 0.10 & 0.05 & -0.18 & 0.03 & $0.23 *$ & 0.04 & 1 & & & & & \\
\hline 9 & Marketing skills acquired & $0.21 *$ & -0.05 & 0.10 & -0.08 & 0.04 & 0.07 & 0.00 & $0.50 *$ & 1 & & & & \\
\hline 10 & International skills acquired & 0.09 & -0.02 & 0.16 & -0.18 & 0.06 & $0.20 *$ & -0.03 & $0.20 *$ & $0.45^{*}$ & 1 & & & \\
\hline 11 & Technological capabilities & $0.21 *$ & 0.16 & 0.15 & -0.01 & $-0.30 *$ & 0.09 & $0.21 *$ & 0.08 & 0.05 & $0.18^{*}$ & 1 & & \\
\hline 12 & Entrepreneurial orientation & $0.20 *$ & -0.09 & -0.01 & -0.04 & 0.15 & 0.04 & 0.15 & 0.14 & 0.12 & 0.18 & 0.12 & 1 & \\
\hline 13 & Support & 0.15 & 0.10 & 0.05 & $-0.20 *$ & 0.04 & 0.06 & 0.16 & $0.21 *$ & 0.08 & 0.10 & 0.07 & 0.15 & 1 \\
\hline
\end{tabular}




\section{REFERENCES}

Bigliardi, B., Galati, F. and Verbano, C. (2013) Evaluating Performance of University Spin-Off Companies: Lessons from Italy, Journal of technology management \& innovation, 8(2), pp. 2930 .

Brush, C. and Lichtenstein, B. M. (2001) How do 'Resource Bundles' Develop and Change in New Ventures? A Dynamic Model and Longitudinal Exploration, Entrepreneurship Theory and Practice, [online] Available from: http://digitalknowledge.babson.edu/eshppw/37 (Accessed 27 March 2015).

Clarysse, B. and Moray, N. (2004) A process study of entrepreneurial team formation: the case of a research-based spin-off, Journal of Business Venturing, Technoentrepreneurship, 19(1), pp. $55-79$.

Colombo, M. G. and Piva, E. (2008) Strengths and Weaknesses of Academic Startups: A Conceptual Model, IEEE Transactions on Engineering Management, 55(1), pp. 37-49.

Criaco, G., Minola, T., Migliorini, P. and Serarols-Tarrés, C. (2014) "To have and have not": founders' human capital and university start-up survival, The Journal of Technology Transfer, 39(4), pp. 567-593.

Datta, A., Mukherjee, D. and Jessup, L. (2014) Understanding commercialization of technological innovation: taking stock and moving forward, $R \& D$ Management, [online] Available from: http://onlinelibrary.wiley.com.www.ezp.biumontpellier.fr/doi/10.1111/radm.12068/abstract (Accessed 26 March 2015).

Di Gregorio, D. and Shane, S. (2003) Why do some universities generate more start-ups than others?, Research Policy, 32(2), pp. 209-227.

Gilsing, V. A., van Burg, E. and Romme, A. G. L. (2010) Policy principles for the creation and success of corporate and academic spin-offs, Technovation, 30(1), pp. 12-23.

Griliches, Z. (1990) Patent Statistics as Economic Indicators: A Survey, Working Paper, National Bureau of Economic Research, [online] Available from: http://www.nber.org/papers/w3301 (Accessed 27 March 2015).

Heirman, A. and Clarysse, B. (2004) How and Why do Research-Based Start-Ups Differ at Founding? A Resource-Based Configurational Perspective, The Journal of Technology Transfer, 29(3/4), pp. 247-268.

Kerr, W. R., Lerner, J. and Schoar, A. (2014) The Consequences of Entrepreneurial Finance, Review of Financial Studies, 27(1), [online] Available from: http://www.hbs.edu/faculty/Pages/item.aspx?num=40781 (Accessed 27 March 2015).

Lee, C., Lee, K. and Pennings, J. M. (2001) Internal capabilities, external networks, and performance: a study on technology-based ventures, Strategic Management Journal, 22(6-7), pp. 615-640. 
Lev, B. and Zarowin, P. (1999) The Boundaries of Financial Reporting and How to Extend Them, Journal of Accounting Research, 37(2), p. 353.

Lin, B.-W., Li, P.-C. and Chen, J.-S. (2006) Social capital, capabilities, and entrepreneurial strategies: a study of Taiwanese high-tech new ventures, Technological Forecasting and Social Change, 73(2), pp. 168-181.

Lockett, A., Siegel, D., Wright, M. and Ensley, M. D. (2005) The creation of spin-off firms at public research institutions: Managerial and policy implications, Research Policy, 34(7), pp. 981-993.

Lockett, A. and Wright, M. (2005) Resources, capabilities, risk capital and the creation of university spin-out companies, Research Policy, 34(7), pp. 1043-1057.

Lumpkin, G. T. and Dess, G. G. (2001) Linking two dimensions of entrepreneurial orientation to firm performance: The moderating role of environment and industry life cycle, Journal of Business Venturing, 16(5), pp. 429-451.

McQueen, D. H. and Wallmark, J. T. (1982) Spin-off companies from Chalmers University of Technology, Technovation, 1(4), pp. 305-315.

Mosey, S. and Wright, M. (2007) From human capital to social capital: A longitudinal study of technology-based academic entrepreneurs, Entrepreneurship Theory and Practice, 31(6), pp. 909-935.

Mustar, P., Renault, M., Colombo, M. G., Piva, E., Fontes, M., Lockett, A., Wright, M., Clarysse, B. and Moray, N. (2006) Conceptualising the heterogeneity of research-based spinoffs: A multi-dimensional taxonomy, Research Policy, 35(2), pp. 289-308.

Ortín-Ángel, P. and Vendrell-Herrero, F. (2014) University spin-offs vs. other NTBFs: Total factor productivity differences at outset and evolution, Technovation, 34(2), pp. 101-112.

O'shea, R. P., Chugh, H. and Allen, T. J. (2008) Determinants and consequences of university spinoff activity: a conceptual framework, Journal of Technology Transfer, 33(6), pp. 653-666.

Pena, I. (2004) Business Incubation Centers and New Firm Growth in the Basque Country, Small Business Economics, 22(3/4), pp. 223-236.

Rasmussen, E., Mosey, S. and Wright, M. (2011) The Evolution of Entrepreneurial Competencies: A Longitudinal Study of University Spin-Off Venture Emergence, Journal of Management Studies, 48(6), pp. 1314-1345.

Rauch, A., Wiklund, J., Lumpkin, G. T. and Frese, M. (2009) Entrepreneurial orientation and business performance: An assessment of past research and suggestions for the future, Entrepreneurship Theory and Practice, 33(3), pp. 761-787. 
Somsuk, N. and Laosirihongthong, T. (2014) A fuzzy AHP to prioritize enabling factors for strategic management of university business incubators: Resource-based view, Technological Forecasting and Social Change, 85, pp. 198-210.

Stéphany, E. (2015) Le financement par les business angels, In Le financement de l'innovation : Nouvelles perspectives théoriques \& pratiques, Edition de Boeck, pp. 63-75.

Unger, J. M., Rauch, A., Frese, M. and Rosenbusch, N. (2011) Human capital and entrepreneurial success: A meta-analytical review, Journal of Business Venturing, 26(3), pp. 341-358.

Vanaelst, I., Clarysse, B., Wright, M., Lockett, A., Moray, N. and S'Jegers, R. (2006) Entrepreneurial Team Development in Academic Spinouts: An Examination of Team Heterogeneity, Entrepreneurship Theory and Practice, 30(2), pp. 249-271.

Vincett, P. S. (2010) The economic impacts of academic spin-off companies, and their implications for public policy, Research Policy, 39(6), pp. $736-747$.

Vohora, A., Wright, M. and Lockett, A. (2004) Critical junctures in the development of university high-tech spinout companies, Research Policy, 33(1), pp. 147-175.

Walter, A., Auer, M. and Ritter, T. (2006) The impact of network capabilities and entrepreneurial orientation on university spin-off performance, Journal of Business Venturing, Entrepreneurship and Strategic Alliances, 21(4), pp. 541-567.

Wright, M. (2007) Academic Entrepreneurship in Europe, Edward Elgar Publishing.

Wright, M. and Stigliani, I. (2013) Entrepreneurship and growth, International Small Business Journal, 31(1), pp. 3-22.

Zahra, S. A. and Nielsen, A. P. (2002) Sources of capabilities, integration and technology commercialization, Strategic Management Journal, 23(5), pp. 377-398.

Zhao, Y. L., Song, M. and Storm, G. L. (2013) Founding Team Capabilities and New Venture Performance: The Mediating Role of Strategic Positional Advantages, Entrepreneurship Theory and Practice, 37(4), pp. 789-814.

Zott, C. and Huy, Q. N. (2007) How Entrepreneurs Use Symbolic Management to Acquire Resources, Administrative Science Quarterly, 52(1), pp. 70-105. 